\title{
A Rare Co-incidental Presentation: Multiple Myeloma and Pleural Adenocarcinoma: A Case Report
}

\author{
Osman YOKUS ${ }^{1}$, Murat ALBAYRAK ${ }^{2}$, Ozlem S. BALCIK ${ }^{2}$, Suleyman S. GOKALP', \\ Mehmet ERSAYDI $^{3}$, Mustafa AKAR ${ }^{4}$, Yucel TEKIN ${ }^{5}$, Hatice K. BOZKURT ${ }^{5}$ \\ ${ }^{1}$ Kayseri Education and Research Hospital, Department of Hematology, Kayseri \\ ${ }^{2}$ Oncology Education and Research Hospital, Department of Hematology, Ankara \\ ${ }^{3}$ Kayseri Education and Research Hospital, Department of Biochemistry, Kayseri \\ ${ }^{4}$ Erciyes University Faculty of Medicine, Department of Internal Medicine, Kayseri \\ ${ }^{5}$ Kayseri Education and Research Hospital, Department of Pathology, Kayseri, TURKEY
}

\begin{abstract}
In this case report we overview the diagnostic and therapeutic approaches for pleural effusions encountered during the treatment and follow-up of patients with myeloma in the light of the current medical literature. A 73-year-old female patient with a stage IIIA multiple myeloma was being treated with melphalan and methyl prednisolone. In the third month of the treatment, she had complaints of coughing, dyspnea and right side pain. Computed tomographic examination of the thorax revealed pleural effusion. Pathological examinations of the pleural fluid and pleural biopsy specimen were compatible with adenocarcinoma. Repeated examinations did not reveal a progression in myeloma or a pleural involvement of myeloma. The patient died of respiratory insufficiency due to the progression of the pleural adenocarcinoma.
\end{abstract}

Keywords: Multiple myeloma, Pleural adenocarcinoma, Pleural effusion

\section{ÖZET}

\section{Nadir Görülen Birliktelik: Multipl Miyelom ve Plevral Adenokarsinom: Olgu Sunumu}

Bu olgu sunumunda miyelom hastalarının takip ve tedavisi esnasında ortaya çıkan plevral efüzyonlara tanısal ve terapotik yaklaşım güncel medical literatür ışığında gözden geçirilmiştir. Evre-IIIA MM'lu 73 yaşında bayan hastaya melfalan ve metil prednizolon tedavisi başlandı. Tedavinin üçüncü ayında öksürük, nefes darlığı ve sağ yan ağrısı şikayetleri başladı. Toraks bilgisayarlı tomografide plevral effüzyon saptandı. Plevral mayi ve plevra biyopsisinin patolojik incelemesi adenokarsinom ile uyumlu bulundu. Tekrarlanan tetkiklerle miyelomda bir ilerleme veya miyelom plevral tutulumunun olmadığı doğrulandı. Hasta plevral adenokarsinomun ilerlemesi sonucu solunum yetmezliğinden kaybedildi.

Anahtar Kelimeler: Multipl miyelom, Plevral adenokarsinom, Plevral effüzyon 


\section{CASE HISTORY}

In this paper, we report a case of multiple myeloma (MM) that developed a pleural effusion during the treatment period. The etiopathological investigations of the effusion revealed adenocarcinoma. A 73-yearold female patient presented to the hematology outpatient clinic with complaints of back ache and weakness. Her clinical laboratory analyses demonstrated anemia and an elevated eryhtrocyte sedimentation rate along with monoclonal gammopathy in her serum protein electrophoresis. The results of the laboratory analyses have been summarized in Table 1 . A total of 500 cells were counted in the bone marrow aspirate and an atypical plasma cell infiltration of $80 \%$ was detected. Bone radiography revealed multiple lytic lesions in the lumbar vertebral corpi. The patient was diagnosed with $\mathrm{IgG}$ lambda MM Durie-Salmon Stage IIIA (Figure 1).

A treatment consisting of melphalan, methyl prednisolone and biphosphonate was initiated. After a 3-months treatment, the patient developed complaints of right side pain, shortness of breath and coughing. In her physical examination of the chest, breath sounds could not be detected in the right lung basal zone and dullness was detected on percussion. Her radiological (postero-anterior chest X-ray) and computed tomographic (CT) examination of the thorax revealed encysted pleural fluid retantion. The pleural fluid was drained by thorasynthesis. Microbiological investigation of the pleural fluid did not reveal any significant pathology.

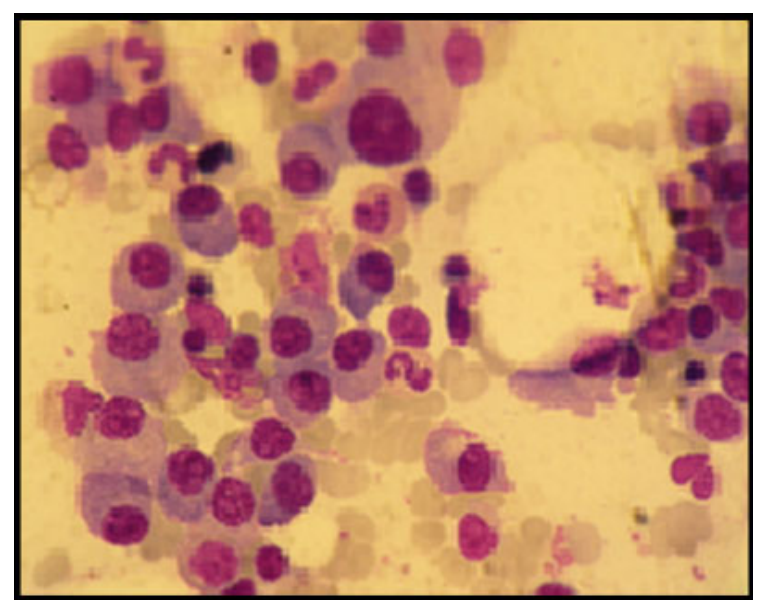

Figure 1. Atypical plasma cells (80\%) in bone marrow aspirate smear (Giemsa x100)
Table 1. Patient characteristics

\begin{tabular}{|c|c|}
\hline Age (years) & 73 \\
\hline Gender & Female \\
\hline Hemoglobin (g/dL) & $9.0(14-17.5)$ \\
\hline Hct & $28 \%$ \\
\hline $\mathrm{BUN}^{*}(\mathrm{mg} / \mathrm{dL})$ & $13(7-26)$ \\
\hline Creatinine $^{\star}(\mathrm{mg} / \mathrm{dL})$ & $0.8(0.6-1.3)$ \\
\hline Calcium (mg/dL) & $9.2(8.4-10.6)$ \\
\hline Albumin* (g/dL) & $3.0(3.5-5)$ \\
\hline $\mathrm{LDH}^{\star}(\mathrm{U} / \mathrm{L})$ & $393(140-280 U / L)$ \\
\hline $\mathrm{CRP}^{*}(\mathrm{mg} / \mathrm{L})$ & $(0-5)$ \\
\hline $\mathrm{ESR}^{\star \star}(\mathrm{mm} / \mathrm{hour})$ & $120(0-25)$ \\
\hline $\lg G^{\star}(g / L)$ & $38.5(6.5-16)$ \\
\hline $\lg A^{*}(g / L)$ & $0.251(0.4-4,9)$ \\
\hline $\operatorname{lgM}^{*}(g / L)$ & $0.175(0.4-3.5)$ \\
\hline \multirow{2}{*}{\multicolumn{2}{|c|}{$\begin{array}{l}\text { Lambda light chain: } 3500(313-723) \\
\text { Kappa light chain: } 186(629-1350)\end{array}$}} \\
\hline & Kappa light chain: 186 (629 - 1350) \\
\hline \multicolumn{2}{|c|}{ 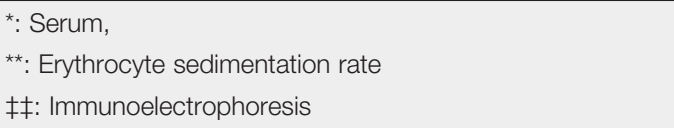 } \\
\hline
\end{tabular}

Immunoelectrophoresis studies have demonstrated an elevated lambda light chain concentration of 749 $\mathrm{mg} / \mathrm{dL}$ (lower limit $723 \mathrm{mg} / \mathrm{dL}$ ) and kappa light chain concentration of $176 \mathrm{mg} / \mathrm{dL}$ (lower limit 629). In addition, the cytological investigation of the pleural fluid sediment by Giemsa staining demonstrated plasmocytoid cells. In the light of these findings, the patient was first considered as a resistant myeloma case and thus thalidomide (100 $\mathrm{mg} /$ day $)$ and bortezomib $\left(1.3 \mathrm{mg} / \mathrm{m}^{2} /\right.$ day; on days $1,4,8$ and 11) were added to the treatment protocol. Simultaneous control of the bone marrow revealed a plasma cell ratio of $4-5 \%$ and the concentrations of lambda and kappa light chains in serum immunoelectrophoresis were $1070 \mathrm{mg} / \mathrm{dL}$ (313-723 $\mathrm{mg} / \mathrm{dL})$ and $1050 \mathrm{mg} / \mathrm{dl}(629-1350 \mathrm{mg} / \mathrm{dL})$, lambda and kappa, respectively. Thus, the patient was considered as VGPR (very good partial response) according to the International Myeloma Working Group uniform response criteria. ${ }^{2}$ In the light of 


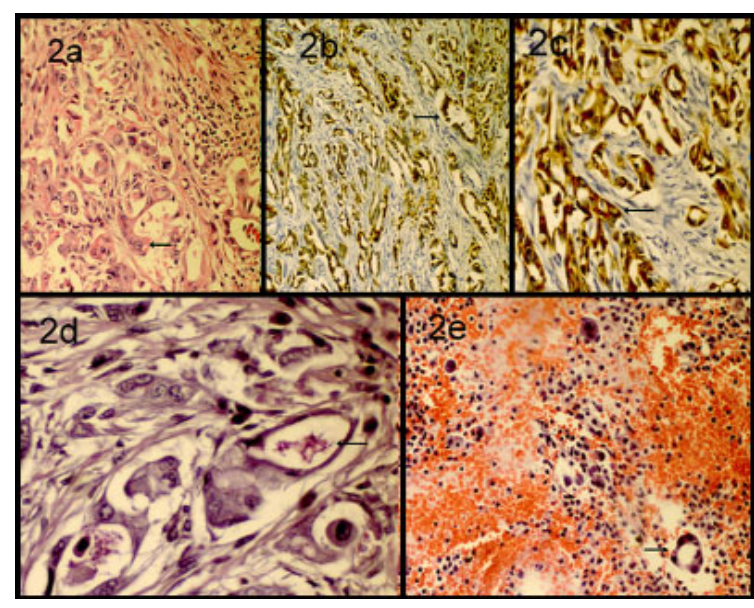

Figure 2a. Adenocarcinoma, x400 (H/E),b. Adenocarcinoma, keratin 20-positivity, c. Adenocarcinoma, CEA positivity d. Adenocarcinoma, focal luminal mucin positivity

e. Adenocarcinoma, atypical cells and adenoid structures in cell block material

these findings, which weakened a possibility of pleural involvement, further investigations were planned. A pleural biopsy was performed and pleural fluid was collected for further pathological investigations. The result of the cytopathological examination stated "malignant cells on a proteinous background occasionally forming groups”. Immunohistochemical staining was positive for carcinoembryonic antigen (CEA) and keratin and negative for vimentin and calretinin. In the light of these results, the pleural fluid specimen was considered to be compatible with adenocarcinoma (Figures 2a, b, c, d, e). Since the increasing amount of pleural effusion caused shortness of breath in the patient, thorasynthesis and pleurodesis procedures were performed to relieve the complaint.

The pleural effusion aggravated in about two weeks, and there were painful nodules and subcutaneous swellings ( $4 \times 5 \mathrm{~cm}$ in size) in the thoracic wall. For these reasons, a thoracic CT was performed which revealed the increase in the pleural effusion and the development of solid masses in the subcutaneous tissues (Figure 3). Thorasynthesis was performed together with therapeutic ultrasonography and pleurodesis was repeated for the second time. Similar to the previous reports, the results of the histopathological examinations of the pleural fluid sample and biopsy specimen obtained from the no-

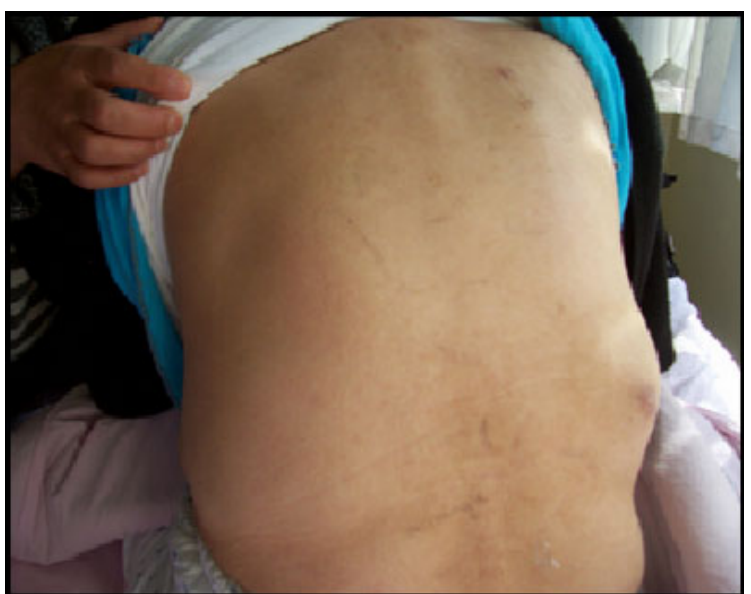

Figure 3. A nodule sized $4 \times 5 \mathrm{~cm}$ in the right postero-lateral wall of the thorax, due to the metastasis of the adenocarcinoma to the subcutaneous tissues

dules by fine needle aspiration were compatible with adenocarcinoma.

After consulting the medical oncology unit of our hospital, we planned further investigations in order to elucidate the primary location of the adenocarcinoma, but the patient refused to undergo further investigations. Analgesic therapy was recommended for the treatment of the back pain as palliative care and the patient was discharged on her own request. Shortly after, the dyspnea and pain complaints of the patient aggravated and she died due to respiratory insufficiency.

\section{DISCUSSION}

Development of a pleural effusion during the course of multiple myeloma is rare but in such cases the prognosis is usually poor. ${ }^{3}$ Malign pleural effusions are most commonly seen in patients with Hodgkin's and non-Hodgkin's lymphoma and among these patients, specifically those with T-cell lymphomas are most commonly affected. The mechanism of development of a pleural effusion is either indirect, due to an obstruction of the thoracic duct and decreased lymphatic drainage or direct such as the result of the infiltration of the pleura with malignant cells. Usually, a differential diagnosis is made by various ancillary studies including immunohistochemical, 
flow-cytometric, cytogenetics/molecular genetic investigations of the effusion specimen. In the absence of obstructive or infiltrative tumor mass, the pathogenesis of pleural or pericardial effusions has been attributed to stimulation by vascular endothelial growth factor (VEGF) and vascular permeability factor (VPF), leading to vascular leakage. ${ }^{4}$ In the developing countries, the commonest etiology of pleural effusions is infections and the commonest etiology of non-hematological malignant pleural effusions is metastatic adenocarcinoma. ${ }^{5}$

In some cases, non-hematological cancers metastasize to the bones and cause multiple osteolytic lesions, bone pains and anemia, thus these symptoms may wrongly be attributed to MM. ${ }^{6}$ When a patient receives a diagnosis such as carcinoma of the prostate, a type of cancer which is known to metastasize to the bone, a simultaneous occurrence of MM should also be investigated. ${ }^{7}$ Besides, the plasmacytoid cytomorphology of some malign cells, such as those encountered in some types of breast cancer, may also be wrongly evaluated as an involvement of MM. In such cases, investigations should not be limited only with morphological findings and further diagnostic approaches should be considered. ${ }^{8}$ Dual occurrence of renal cell carcinoma and MM in the same patient has been previously reported, suggesting an association between these two malignancies and the the probability of this association was much higher than that which could be explained by genetic or immune-mediated common factors. ${ }^{9}$ But to our knowledge, there was no report on a specific coexistence of MM and adenocarcinoma and the probable etiopathogenic mechanisms which might account for this association. Todolí Parra et al. retrospectively analyzed in order to elucidate whether this tumor is in itself a risk factor for the development of second malignancies and whether it has an effect on their incidence in a series of 210 patients with MM. A second malignancy was detected in $33 \%$ of the patients with MM. The authors concluded that the association was observed in $6.2 \%$ of patients with MM and the association even increased at an advanced age. A closer association was found with $\operatorname{IgG}$ myelomas and myelomas in early stages. A short term high mortality rate was observed due to the progression of the solid malignancy.$^{10}$ As similar to these findings, the present ca- se also had IgG myeloma, was at an advanced age and although her myeloma was on partial clinical remission. She could only survive 1.5 months due to the rapid progression of the second malignancy. It is reported that in patients with myeloma, a second neoplasm may develop or co-exist, in greater frequency than that of the general population. ${ }^{11}$

In conclusion, $\mathrm{MM}$ can rarely coexist with non-hematological malignancies and in such cases survival time decreases significantly. If the secondary malignancy develops after the diagnosis of MM, the symptoms that it causes either in the primary location of the cancer or in the location where it makes a metastasis are frequently taken as complications of myeloma and this situation leads to a delay in diagnosis and treatment of the disease. And in some instances, the co-occurrence of MM and a secondary non-hematological cancer may cause similar symptoms thus making the diagnosis more difficult. In the differential diagnosis of pleural effusions developing during the follow-up of patients with MM, although much rarer, a pleural involvement of non-hematological cancers, should also be considered along with the frequently encountered infectious agents leading to pleural effusions.

\section{REFERENCES}

1. Durie BG, Salmon SE. A clinical staging system for multiple myeloma. Correlation of measured myeloma cell mass with presenting clinical features, response to treatment, and survival. Cancer 36: 842-854, 1975.

2. Durie BG, Harousseau JL, Miguel JS, et al. International Myeloma Working Group International uniform response criteria for multiple myeloma. Leukemia 20: 1467-1473, 2006.

3. Kamble R, Wilson CS, Fassas A, et al. Malignant pleural effusion of multiple myeloma: prognostic factors and outcome. Leuk Lymphoma 46: 1137-1142, 2005.

4. Das DK. Serous effusions in malignant lymphomas: a review. Diagn Cytopathol 34: 335-347, 2006.

5. Awasthi A, Gupta N, Srinivasan R, et al. Cytopathological spectrum of unusual malignant pleural effusions at a tertiary care centre in north India. Cytopathology 18: 28-32, 2007.

6. Doval DC, Bhatia K, Vaid AK, et al. Bone metastases from primary hepatocellular carcinoma simulating multiple myeloma. Hepatobiliary Pancreat Dis Int 4: 308310, 2005. 
7. Pérez López ME, García Mata J, García Gómez J, et al. Prostate adenocarcinoma and synchcronous multiple myeloma: a case report. Actas Urol Esp 31: 157159, 2007.

8. Khalbuss WE, Fischer G, Ahmad M, Villas B. Synchronous presentation of breast carcinoma with plasmacytoid cytomorphology and multiple myeloma. Breast $J$ 12: 165-167, 2006.

9. Choueiri TK, Baz RC, McFadden CM, Khasawneh M. An association between renal cell carcinoma and multiple myeloma: A case series and clinical implications. BJU Int 101: 712-715, 2008.

10. Todolí Parra JA, Campo López C, Segura Huerta A. Association of multiple myeloma and solid neoplasms: analysis of 13 cases. Rev Clin Esp 199: 725-728, 1999.

11. Christou L, Tsiara S, Frangides Y, Pnevmatikos J. Patients with multiple myeloma and solid tumors: six case reports. J Exp Clin Cancer Res 17: 239-242, 1998.

\section{Correspondence}

Dr. Özlem ŞAHIN BALÇIK

Dizgi Sok. No: 9/6 06120 Basinevleri

Ankara / TURKEY

Tel: (+90.535) 3758174

Fax: $\quad$ (+90.312) 4910111

E-mail: drozlembalcik@yahoo.com 